Vol IV. No.1, September 2019, hlm. 1 - 11

Available online at www.jurnal.una.ac.id/indeks/jmp

\title{
MODEL KOOPERATIF TIPE MAKE A MATCH BERBASIS MULTIMEDIA PADA PEMBELAJARAN MATEMATIKA
}

\author{
Rizal Cahyadi ${ }^{1}$, Chusnal Ainy ${ }^{2}$, Achmad Hidayatullah ${ }^{3}$ \\ Program Studi Pendidikan Matematika \\ Universitas Muhammadiyah Surabaya \\ Email: rizalcahyadi15@gmail.com ${ }^{1}$
}

\begin{abstract}
Abstrak
Penelitian ini dilakukan karena rendahnya aktivitas dan hasil belajar peserta didik pada mata pelajaran matematika. Penelitian ini bertujuan untuk mengetahui penerapan pembelajaran kooperatif tipe make a match berbasis multimedia dalam meningkatkan aktivitas dan hasil belajar peserta didik kelas VIII A di MTs YATABU Surabaya pada mata pelajaran matematika materi statistika. Penelitian ini merupakan penelitian tindakan kelas (classroom action research). Penelitian ini dilakukan dalam dua siklus dan setiap akhir siklus peserta didik mengerjakan soal tes sebagai evaluasi hasil belajar peserta didik. Teknik pengumpulan data menggunakan lembar observasi, tes, dan dokumentasi. Berdasarkan hasil analisis data yang diperoleh, persentase aktivitas peserta didik dalam satu kelas pada pertemuan ke-1 siklus I sebesar $58 \%$, mengalami peningkatan pada siklus II pertemuan ke-2 yaitu menjadi 73,61 \% dan pertemuan ke-3 menjadi 84,03 \% sehingga rata-rata sebesar $78,82 \%$. Peningkatan hasil belajar peserta didik dapat dilihat dari persentase ketuntasan belajar peserta didik pada siklus I sebesar $72 \%$, mengalami peningkatan sebesar 83,33\% pada siklus II. Nilai rata-rata peserta didik dalam satu kelas juga mengalami peningkatan yaitu dari 74,44 pada siklus I menjadi 77,38 pada siklus II.
\end{abstract}

Kata Kunci: make a match berbasis multimedia; aktivitas; hasil belajar.

\begin{abstract}
This research was conducted because of the low activity and learning outcomes of students in mathematics. This study aims to determine the application of multimedia-based make a match type of cooperative learning in enhancing the learning activities and learning outcomes of Class VIII A students at MTS YATABU Surabaya in mathematics subject matter statistics. This research is a classroom action research. This research was conducted in two cycles and at the end of each cycle the students worked on the test questions as an evaluation of student learning outcomes. Data collection techniques using observation sheets, tests, and documentation. Based on the analysis of the data obtained, the percentage of student activity in one class at the first meeting of the first cycle was 58\%, an increase in the second cycle of the second meeting which was $73.61 \%$ and the third meeting became $84.03 \%$ so that an average of $78.82 \%$. Increased student learning outcomes can be seen from the percentage of students completeness learning in the first cycle by $72 \%$, an increase of $83.33 \%$ in the second cycle. The average value of students in one class also increased, from 74.44 in the first cycle to 77.38 in the second cycle.
\end{abstract}

Keywords: make a match based on multimedia; activity; learning outcomes 
Vol IV. No.1, September 2019, hlm. 1 - 11

Available online at www.jurnal.una.ac.id/indeks/jmp

\section{PENDAHULUAN}

Matematika adalah ide abstrak yang digunakan untuk mengelompokkan terhadap objek matematika. Matematika adalah salah satu bidang ilmu yang memiliki peranan penting dalam kehidupan sehari-hari (Ainy, 2009: 15). Matematika menurut Simamora (2014:24). Berasal dari kata latin mathematica yang diambil dari kata Yunani mathematike yang artinya bertalian dengan pengetahuan. Kata Yunani itu mempunyai akar kata mathema yang berarti ilmu, pengetahuan (Science, knowledge). Banyak berbagai permasalahan dapat dipecahkan dengan menggunakan konsep matematika. Selain itu, banyak cabang ilmu pengetahuan dan teknologi yang memerlukan matematika untuk pengembangannya. Dalam kehidupan sehari-hari matematika adalah suatu ilmu yang diperlukan untuk mengembangkan cara berpikir sebagai pengembangan kemajuan ilmu pengetahuan dan teknologi (Offirstson, 2014: 1). Menurut Hanum (2017: 74) Matematika merupakan salah satu ilmu dasar yang mempunyai peranan penting baik dalam kehidupan sehari-hari maupun dalam pengembangan ilmu dan teknologi. Matematika juga ilmu utama yang mendasari perkembangan teknologi. Matematika sering dipandang sebagai bahasa ilmu, alat komunikasi antara ilmu dan ilmuwan serta merupakan alat analisis data. Dengan demikian matematika sebagai sarana strategis dalam mengembangkan kemampuan dan keterampilan intelektual. Mengingathal tersebut, sudah seharusnya konsep-konsep dalam matematika dapat dipelajari dan dikuasi oleh peserta didik. Belajar menurut Hidayatullah (2018: 3) adalah suatu proses yang kompleks yang terjadi pada setiap insan yang berlangsung seumur hidup, dimulai dari bayi (bahkan dalam kandungan) hingga liang lahat. Sedangkan menurut Mufidah (2013: 117) Belajar adalah sebuah kegiatan dalam mengembangkan diri atau tingkah lakubaik dalam aspek kognitif, psikomotorik maupun sikap.

Namun pada kenyataanya, pembelajaran matematika di lapangan ditemukan masih banyak yang menggunakan sistem pembelajaran model teacher centered learning atau pembelajaran berpusat pada guru. Menurut Sudjana (2005: 39) pembelajaran model teacher centered learning guru lebih mendominasi proses pembelajaran yang berbentuk ceramah, peran peserta didik hanya sebatas memahami, bagi yang merasa memerlukan mereka akan membuat catatan. Pada pembelajaran ini seakan-akan guru menjadi pusat dalam perolehan hasil dan menjadi sumber ilmu semata. Model ini hanya sebatas transfer pengetahuan yang memberikan penjelasan satu arah dengan menempatkan guru sebagai pemateri dan peserta didik sebagai penerima materi, karena yang ingin dicapai adalah bagaimana guru mampu mengajar dengan baik. Hal tersebut dapat mengakibatkan peserta didik kurang aktif dan lebih cepat bosan dalam mengikuti proses pembelajaran. Fenomena itu banyak terjadi di sekolah, salah satunya di MTs. YATABU Surabaya. 
Vol IV. No.1, September 2019, hlm. 1 - 11

Available online at www.jurnal.una.ac.id/indeks/jmp

Oleh karena itu, perlu ada perubahan model pembelajaran agar peserta didik menjadi lebih aktif, salah satunya dengan menggunakan model pembelajaran kooperatif yang mengikutsertakan seluruh peserta didik. Suprapti (2016: 59) menjelaskan bahwa model pembelajaran kooperatif juga mengutamakan kerja sama dalam menyelesaikan suatu permasalahan untuk menerapkan pengetahuan dan keterampilan untuk mencapai tujuan pembelajaran. Ismawati (2011: 39) menjelaskan Pembelajaran kooperatif merupakan suatu modelpembelajaran dimana siswa belajar dalam kelompok-kelompok kecil yang memiliki tingkat kemampuanberbeda. Dalam menyelesaikan tugas kelompok, setiapanggota saling kerjasama dan membantu untukmemahami suatu bahan pembelajaran.Pembelajaran kooperatifmenggunakan kelompokkelompok kecilsehingga mahasiswa saling bekerja sama untukmencapai tujuan pembelajaran (Suprapti, 2013: 61). Banyak pilihan model pembelajaran kooperatif, salah satunya tipe make a match. Model ini dapat menjadi solusi permasalahan yang ada di kelas VIII A MTs. YATABU Surabaya. Model tersebut merupakan salah satu model yang dapat meningkatkan aktivitas belajar peserta didik baik dalam aspek kognitif maupun psikomotorik, dan motivasi belajar karena model pembelajaran ini menyenangkan dengan unsur permainan. Selain aspek kognitif dan psikomotorik, model pembelajaran make a match juga melatih peserta didik dalam aspek afektif, yaitu melatih keberanian peserta didik untuk tampil berprestasi dan melatih kedisiplinan dalam menghargai waktu (Huda, 2013: 253-254).

Penggunaan multimedia sebagai media bantu dalam penerapan model pembelajaran kooperatif tipe make a match dalam evaluasi belajar akan lebih menarik perhatian peserta didik dalam mengikuti pembelajaran matematika dengan baik. Menurut Munir (2012: 127) multimedia memiliki kelebihan yang bisa diandalkan sebagai media pendidikan dibandingkan dengan media-media lain, karena multimedia mampu mencakup berbagai media, seperti teks, suara, gambar, grafik, dan animasi dalam satu sajian digital. Multimedia juga memiliki akses interaktif dengan pengguna. Suprapti (2016: 58) menjelaskan pembelajaran dengan berbantuan multimedia juga dapat mempermudah dalam menyampaikan materi pada saat kegiatan pembelajaran. Keberadaan multimedia dalam pendidikan telah menunjukan suatu perkembangan baru yang diharapkan mampu membantu dunia pendidikan menjadi lebih bermakna melalui pembelajaran. Bahkan untuk menarik minat peserta didik perlu menggunakan strategi pemanfaatan multimedia dalam kurikulum pendidikan.

Pada penelitian ini, model pembelajaran kooperatif tipe make a match dikombinasikan dengan multimedia untuk meningkatkan aktivitas belajar matematika. Kombinasi keduanya disajikan dalam bentuk aplikasi yang menyenangkan dan dapat dijalankan pada smartphone yang melibatkan seluruh peserta didik pada pembelajaran 
Vol IV. No.1, September 2019, hlm. 1 - 11

Available online at www.jurnal.una.ac.id/indeks/jmp

matematika. Menurut Hidayatullah (2016: 62) pembelajaran matematika perlu adanya perubahan dalam bentuk permainan edukatif, sehingga merubah anggapan peserta didik bahwa pelajaran matematika bukan lagi pelajaran yang membosankan tetapi pelajaran yang menyenangkan. Selain itu, dengan menerapkan model ini juga mampu meningkatkan hasil belajar matematika, karena dengan penerapan make a match peserta didik bisa memperdalam pemahamannya atas apersepsi atau materi pelajaran yang telah disampaikan sebelumnya melalui permainan mencari pasangan yang menyenangkan sehingga pemahaman peserta didik dapat terekam dengan baik.Menurut Shoffa (2017: 181) hasil belajar dapat menunjukkan kemampuan peserta didik dalam menguasai dan memahami materi yang berupa nilai.

Model kooperatif tipe make a match pada pembelajaran matematika juga dapat menciptakan suasana persaingan sehat antara peserta didik. Persaingan tersebut dilakukan ketika peserta didik mencari pasangan dari soal yang mereka kerjakan. Persaingan dalam proses pembelajaran akan menimbulkan upaya belajar yang sungguh-sungguh. Sesuai dengan prinsip individu yang ingin selalu lebih baik dari individu yang lain. Sedangkan pemberian penghargaan merupakan cara yang efektif untuk meningkatkan aktivitas belajar peserta didik menuju pada hasil belajar yang lebih baik. Menurut Afridati (2018) aktivitas belajar merupakansuatu kegiatan atau aktivitas yang disusun secara sadar untuk dilakukan seseorang yang mengakibatkan perubahan dalam dirinya, perubahan perilaku, pengetahuan yang sifatnya tergantung pada sedikit banyaknya perubahan.Meier (dalam Darmayanti, 2007: 64) membagi aktivitas belajar menjadi empat kategori, yakni: (1) Somatis adalah belajar dengan fisik atau belajar dengan berbuat dan bergerak; (2) Auditori adalah belajar dengan menggunakan indra pendengaran atau belajar dengan mendengar dan berbicara; (3) Visual adalah belajar dengan menggunakan indra penglihatan atau belajar dengan mengamati dan menggambarkan; (4) Intelektual adalah belajar dengan menalar, merencanakan, berpikir abstrak dan memecahkan masalah.

\section{METODE}

Penelitian ini merupakan penelitian tindakan kelas (classroom action research).Penelitian ini menggunakan model Kemmis \& McTaggart yang berbentuk spiral dari siklus satu ke siklus berikutnya.Setiap siklus terdiri dari empat kegiatan putaran berulang, yaitu perencanaan (plan), tindakan (act), pengamatan (observe), dan refleksi (reflect). Adapun langkahlangkah rencana tindakan yang akan dilaksanakan dalam penelitian ini dengan menggunakan model pembelajaran kooperatif tipe make a match berbasis multimedia: (1) Tahap refleksi awal yaitu identifikasi permasalahan pembelajaran matematika; (2) Tahap rencana tindakan yaitu, menyamakan persepsi, Menyusun Rencana Pelaksanaan Pembelajaran (RPP) beserta Lembar Kerja Peserta Didik (LKPD), Menyiapkan media make a match berbasis multimedia, 
Vol IV. No.1, September 2019, hlm. 1 - 11

Available online at www.jurnal.una.ac.id/indeks/jmp

Menentukan alat pengumpulan data yang digunakan untuk mengamati jalannya proses pembelajaran, yaitu berupa lembar observasi aktivitas belajar peserta didik, keterlaksanaan pembelajaran, tes hasil belajar, dan alat dokumentasi; (3) Tahap pelaksanaan tindakan guru melaksanakan pembelajaran sesuai RPP (Rencana Pelaksanaan Pembelajaran) yang telah dirancang sebelumnya; (4) Tahap observasi dilakukan pada saat kegiatan proses pembelajaran berlangsung untuk memperoleh data yang diperlukan untuk mengetahui hasil penerapan pembelajaran kooperatif tipe make a match berbasis multimedia; (5) Tahap refleksi dilakukan untuk memahami hal-hal yang berkaitan dengan proses dan hasil yang diperoh dari tindakan yang telah dilakukan.

\section{HASIL DAN PEMBAHASAN}

Berdasarkan pelaksanan penelitian yang dilaksanakan pada bulan Mei tahun 2019 yang terdiri dari dua siklus penelitian hasil penelitian ini dikelompokan dalam tiga bagian yaitu, aktivitas peserta didik, keterlaksanaan pembelajaran, dan hasil belajar.

\section{a. Penerapan Pembelajaran Kooperatif Tipe Make a match Berbasis Multimedia untuk Meningkatkan Aktivitas Peserta Didik}

Setelah dilakukan penelitian terhadap peserta didik kelas VIII A MTs YATABU Surabaya pada mata pelajaran matematika materi statistika dengan menerapkan model pembelajaran kooperatif tipe make a match berbasis multimedia dapat diketahui adanya peningkatan aktivitas peserta didik. Pada siklus I yang dilaksanakan pada pertemuan ke-1 memperoleh rata-rata persentase aktivitas peserta didik yang dapat di lihat pada tabel 4.4 dengan persentase $58 \%$ yang masih belum memenuhi kriteria yang diharapkan. Pada siklus II yang dilaksanakan pada pertemuan ke-2 dan pertemuan ke-3, dengan adanya perbaikan pembelajaran dari pertemuan ke-1 siklus I, pembelajaran pada siklus II dapat berjalan dengan optimal. Dapat di lihat pada tabel 4.14 data rekapitulasi aktivitas peserta didik pada siklus II diperoleh rata-rata dari pertemuan ke-2 dan pertemuan ke-3 dengan rata-rata persentase aktivitas peserta didik sebesar 78,82\% dari hasil rata-rata persentase dari pertemuan ke-2 dan pertemuan ke-3 pada siklus II. Sehingga, persentase pada siklus II sudah melebihi kriteria yang telah ditentukan peneliti, yaitu aktivitas peserta didik dapat dikatakan meningkat apabila ratarata persentase aktivitas peserta didik sekurang-kurangnya $\quad 75 \%$ dari jumlah peserta didik dalam satu kelas. Untuk lebih jelasnya berikut data hasil rekapitulasi aktivitas peserta didik pada siklus I dan siklus II dapat dilihat pada tabel 1 . 
Vol IV. No.1, September 2019, hlm. 1 - 11

Available online at www.jurnal.una.ac.id/indeks/jmp

Tabel 4.15 Rekapitulasi Aktivitas Peserta Didik Pada Siklus I dan Siklus II

\begin{tabular}{|c|c|c|c|c|}
\hline \multirow[b]{2}{*}{ No } & \multirow{2}{*}{$\begin{array}{c}\text { Indikator aktivitas peserta } \\
\text { didik }\end{array}$} & \multirow{2}{*}{$\begin{array}{c}\text { Siklus I } \\
\text { Pertemuan } \\
\text { ke-1 }\end{array}$} & \multicolumn{2}{|c|}{ Siklus II } \\
\hline & & & $\begin{array}{c}\text { Pertemuan ke- } \\
2\end{array}$ & $\begin{array}{c}\text { Pertemuan } \\
\text { ke-3 }\end{array}$ \\
\hline 1. & $\begin{array}{l}\text { Memperhatikan dan } \\
\text { mendengarkan penjelasan dari } \\
\text { guru. }\end{array}$ & $72 \%$ & $87,50 \%$ & $95,83 \%$ \\
\hline 2. & $\begin{array}{l}\text { Melaksanakan diskusi kelompok } \\
\text { sesuai dengan petunjuk guru. }\end{array}$ & $68 \%$ & $83,33 \%$ & $91,67 \%$ \\
\hline 3. & $\begin{array}{l}\text { Mencari berbagai informasi yang } \\
\text { diperlukan untuk memecahkan } \\
\text { masalah. }\end{array}$ & $56 \%$ & $70,83 \%$ & $87,50 \%$ \\
\hline 4. & $\begin{array}{l}\text { Berdiskusi dengan peserta didik } \\
\text { lain saat mencari pasangan. }\end{array}$ & $60 \%$ & $87,50 \%$ & $100 \%$ \\
\hline 5. & $\begin{array}{l}\text { Bertanya kepada guru apabila } \\
\text { mengalami kesulitan. }\end{array}$ & $64 \%$ & $75 \%$ & $87,50 \%$ \\
\hline 6. & Menyampaikan ide/pendapat. & $28 \%$ & $37,50 \%$ & $41,67 \%$ \\
\hline \multirow{2}{*}{\multicolumn{2}{|c|}{$\begin{array}{c}\text { Rata-rata persentase aktivitas peserta } \\
\text { didik }\end{array}$}} & $58 \%$ & $73,61 \%$ & $84,03 \%$ \\
\hline & & $58 \%$ & \multicolumn{2}{|c|}{$78,82 \%$} \\
\hline
\end{tabular}

Aktivitas yang banyak dilakukan oleh peserta didik adalah keterlibatan peserta didik dalam berdiskusi. Hal ini dikarenakan antusias peserta didik selama mengikuti kegiatan pembelajaran dengan menggunakan model pembelajaran kooperatif tipe make a match berbasis multimedia, dimana dengan menggunakan model ini semua peserta didik ikut terlibat dalam proses pembelajaran, karena selama ini proses pembelajaran hanya berpusat pada guru dan kurang melibatkan peserta didik untuk aktif dalam mengikuti kegiatan pembelajaran hal tersebut dapat dilihat pada Gambar 1 pada saat peserta didik berdiskusi untuk menyelesakan soal yang ada pada aplikasi.

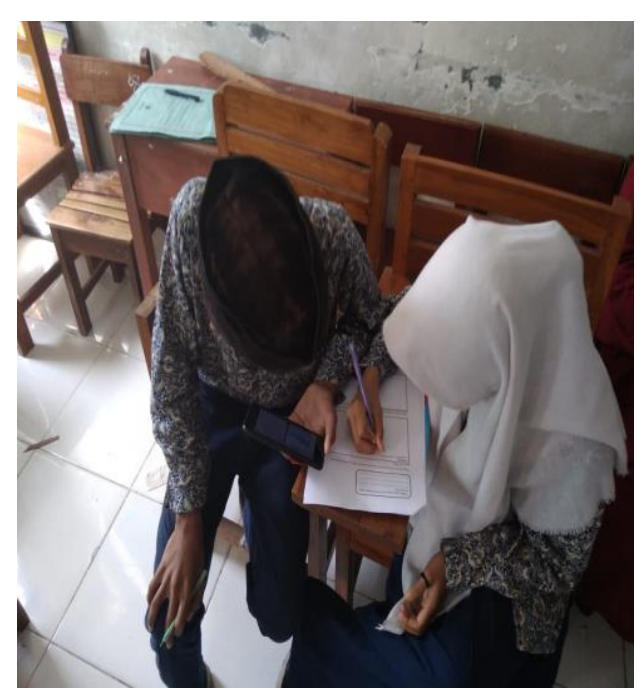

Gambar 1 Berdiskusi Menyelesaikan Soal dalam Aplikasi

Begitu juga pada kegiatan pencocokan soal dan jawaban, peserta didik juga terlihat begitu aktif meskipun pada kegiatan ini kondisi kelas sedikit gaduh, hal tersebut dapat di lihat pada Gambar 2 berikut. 
Vol IV. No.1, September 2019, hlm. 1 - 11

Available online at www.jurnal.una.ac.id/indeks/jmp

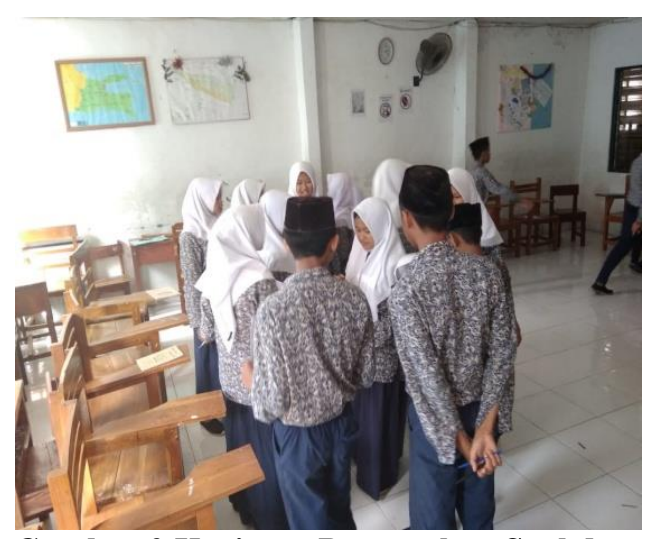

Gambar 2 Kegiatan Pencocokan Soal dan Jawaban

Bagitu juga, ketika peserta didik berdiskusi mencari solusi dari soal dan jawaban yang telah mereka cocokan peserta didik juga terlihat aktif dalam kegiatan ini, hal tersebut dapat dilihat pada Gambar 3 berikut.

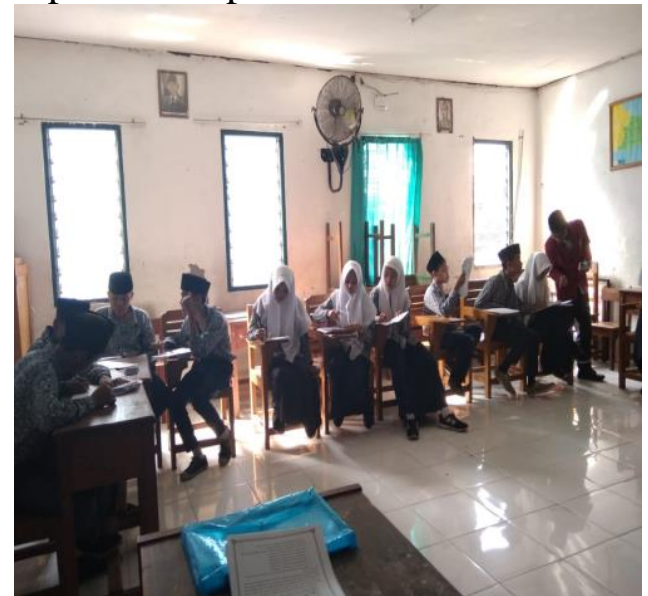

Gambar 3 Berdiskusi Mencari Solusi dari Soal dan Jawaban yang di cocokkan

Berdasarkan hasil penelitian yang telah dilakukan dan merujuk pada teori Meier dalam Darmayanti (2007: 64) yang membagi aktivitas belajar menjadi empat kategori dan kaitannya dengan indikator aktivitas peserta didik yang dilakukan pada penerapan pembelajaran kooperatif tipe make a match berbasis multimedia dapat meningkatkan aktivitas peserta didik selama proses pembelajaran. Hal ini sejalan dengan yang disampaikan oleh Huda (2013: 253-254) modelmake

$a$ matchmerupakan salah satu model yang dapat meningkatkan aktivitas belajar baik dalam aspek kognitif, aspek psikomotorik, aspek afektif dan motivasi belajar peserta didik. Begitu juga dengan multimedia yang dikombinasikan dengan model pembelajaran kooperatif tipe make a match dalam bentuk aplikasi yang menyenangkan yang sejalan dengan yang disampaikan oleh Munir (2012:127) multimedia memiliki kelebihan yang bisa diandalkan sebagai media pendidikan.

\section{b. Penerapan Pembelajaran \\ Kooperatif Tipe Make a match \\ Berbasis Multimedia pada \\ Keterlaksanaan Pembelajaran yang dilakukan Guru}

Kemampuan guru dalam melaksanakan kegiatan pembelajaran pada penelitian ini disesuaikan dengan RPP dengan menerapankan pembelajaran kooperatif tipemake a match berbasis multimedia, berikut rekapitulasi keterlaksanaan pembelajaran pada siklus I dan Siklus II:

Tabel 2 Rekapitulasi Keterlaksanaan Pembelajaran

\begin{tabular}{cccc}
\hline \multirow{2}{*}{ Aktivitas } & Siklus I & \multicolumn{2}{c}{ Siklus II } \\
\cline { 2 - 4 } & Pertemuan Ke-1 & Pertemuan Ke-2 & Pertemuan Ke-3 \\
\hline Jumlah Aktivitas & 20 & 20 & 20 \\
\hline Terlaksana & 17 & 19 & 20 \\
\hline Tidak Terlaksana & 3 & 1 & 0 \\
\hline Persentase & $85 \%$ & $95 \%$ & $100 \%$ \\
\hline Kategori & Sangat baik & Sangat baik & Sangat baik \\
\hline
\end{tabular}


Vol IV. No.1, September 2019, hlm. 1 - 11

Available online at www.jurnal.una.ac.id/indeks/jmp

Data pada tabel 2 di atas, menunjukkan bahwa keterlaksanaan pembelajaran yang dilakukan guru pada pertemuan ke-1 siklus I memiliki kategori sangat baik dengan persentase $85 \%$ ada beberapa aspek yang tidak terlaksana pada pertemuan ke-1, yaitu: (1) Guru menyampaikan tujuan pembelajaran tentang materi pembelajaran yang akan dilaksanakan, (2) Guru mengarahkan peserta didik, memotivasi, dan memberikan bantuan dalam menyelesaikan LKPD, (3) Guru memperhatikan dengan seksama, memotivasi jika ada peserta didik yang tidak terlibat dalam diskusi.

Pertemuan ke-2 dan Pertemuan ke-3 siklus II memiliki kategori sangat baik dengan persentase95\% dan $100 \%$ peningkatan tersebut dikarenakan disetiap akhir pertemuan terdapat refleksi yang bertujuan untuk mengevaluasi kegiatan pembelajaran yang telah dilakukan oleh guru. Pada pertemuan ke-2 ada satu aspek yang tidak terlaksana, yaitu pada pra

Tabel 3 Rekapitulasi Hasil Belajar Peserta Didik

\begin{tabular}{cccc}
\hline Hasil Belajar Peserta Didik & $\begin{array}{c}\text { Sebelum } \\
\text { Tindakan }\end{array}$ & Siklus I & Siklus II \\
\hline Rata-rata & 58,84 & 74,44 & 77,38 \\
\hline $\begin{array}{c}\text { Jumlah Peserta Didik dengan Ketuntasan } \\
\text { Belajar (nilai } \geq \text { 75) }\end{array}$ & 5 & 18 & 20 \\
\hline Persentase Ketuntasan (\%) & 20 & 72 & 83,33 \\
\hline
\end{tabular}

Berdasarkan tabel 3 diatas dapat diketahui bahwa nilai rata-rata sebelum tindakan kelas VIII A yang diambil dari nilai PTS yaitu 58,85 dengan jumlah peserta didik yang memenuhi nilai ketuntasan belajar $\geq$ 75 sebanyak 5 orang dari 25 peserta didik sehingga persentase ketuntasan yaitu $20 \%$. Pada siklus I, nilai rata- kegiatan guru tidak menyiapkan alat/bahan pembelajaran. Sedangkan, pada pertemuan ke-3 Semua aspek dalam lembar observasi keterlaksanaan pembelajaran telah terlaksana.

\section{c. Penerapan Pembelajaran Kooperatif Tipe Make a match Berbasis Multimedia untuk Meningkatkan Hasil Belajar Peserta Didik}

Berdasarkan hasil penelitian yang telah dilaksanakan terhadap peserta didik kelas VIII A MTs YATABU Surabaya dengan menggunakan pembelajaran kooperatif tipe make a match berbasis multimedia mampu meningkatkan hasil belajar peserta didik pada mata pelajaran matematika materi statistika. Hal tersebut dapat dilihat dengan adanya peningkatan hasil belajar peserta didik dari sebelum tindakan, siklus I, dan siklus II. Rekapitulasi hasil belajar secara rinci dapat dilihat pada tabel di bawah ini: 
Vol IV. No.1, September 2019, hlm. 1 - 11

Available online at www.jurnal.una.ac.id/indeks/jmp

ketuntasan belajar $\geq 75$ dari 24 peserta didik dengan persentase ketuntasan belajar sebesar 83,33\%. Sehingga, pembelajaran dengan menerapkan model pembelajaran kooperatif tipe make a match berbasis multimedia sudah memenuhi kriteria peningkatan hasil belajar yang telah ditentukan oleh peneliti yaitu apabila hasil belajar peserta didik sekurang-kurangnya $75 \%$ dari jumlah peserta didik dalam satu kelas telah memenuhi nilai KKM.

Kenaikan hasil belajar peserta didik karena dipengaruhi oleh beberapa faktor, diantaranya: pada saat kegiatan pembelajaran pada siklus II peserta didik sudah mulai terbiasa dengan pembelajaran kooperatif tipe make a match berbasis multimedia, peserta didik juga sudah mulai terbiasa dalam menjalankan aplikasi make a match berbasis multimedia yang terdapat pada smartphone peserta didik dan peserta didik mau berdiskusi secara berkelompok dalam menyelesaiakan LKPD dan aktif bertanya jika peserta didik merasa kesulitan dalam menyelesaikan LKPD, karena materi dalam LKPD akan digunakan dalam permainan dan post test.Hal tersebut karena pembelajaran kooperatif tipe make a match merupakan model pembelajaran yang menyenangkan dengan unsur permainan yang disampaikan oleh Huda (2013: 253254) dan dengan bantuan multimedia yang mana multimedia menurut Munir (2012:127) memiliki kelebihan yang bisa diandalkan sebagai media pendidikan dibandingkan dengan media-media lain.

\section{SIMPULAN}

Berdasarkan hasil penelitian dan pembahasan, penelitian tindakan kelas (classroom action research) pada mata pelajaran matematika materi statistika dapat disimpulkan sebagai berikut.

1. Pelaksanaan pembelajaran pada mata pelajaran matematika materi statistika dengan menggunakan pembelajaran kooperatif tipe make a match berbasis multimedia di kelas VIII A MTs YATABU Surabaya dapat meningkatkan aktivitas peserta didik. Hal ini berdasarkan pengamatan dari semua indikator yang telah ditentukan pada siklus I menunjukkan rata-rata aktivitas peserta didik sebesar 54,49\% dan meningkat menjadi $77 \%$ pada siklus II. Pada siklus I dan siklus II mengalami peningkatan sebesar 22,51\%.

2. Pelaksanaan pembelajaran pada mata pelajaran matematika materi statistika dengan menggunakan pembelajaran kooperatif tipe make a match berbasis multimedia di kelas VIII A MTs YATABU Surabaya dapat meningkatkan hasil belajar peserta didik. Hal ini berdasarkan hasil post test pada siklus I dengan persentase ketuntasan sebesar 73,08\%kemudian meningkat menjadi $84 \%$ pada siklus II. Nilai rata-rata kelas juga meningkat dari siklus I sebesar 74,27 meningkat menjadi 77,68 pada siklus II. 
Vol IV. No.1, September 2019, hlm. 1 - 11

Available online at www.jurnal.una.ac.id/indeks/jmp

\section{DAFTAR RUJUKAN}

Ainy, Chusnal. (2009). Strategi Meningkatkan Pemahaman Konsep dan Kemampuan Komunikasi Matematika. Didaktis. Vol. 8, No. 3.

Darmayanti, Nani. (2007). Bahasa Indonesia untuk Sekolah Menengah Kejuruan Tingkat Media (Kelas XI). Jakarta: Grafindo Media Pratama.

Hanumi, Farida., Chusnal Ainy., Endang Suprapti. (2017). Pembelajaran Matematika Melalui Metode Thinking Aloud Pair Problem Solving Dalam Meningkatkan Kemampuan Siswa Kelas ViiB Smp Muhammadiyah 13 Surabaya. Journal of Mathematics Education, Science and Technology. Vol. 2, No. 1.

Hidayatullah, Achmad. (2016). Upaya Menumbuhkan Kreativitas Anak Dengan Permainan Matematika. Jurnal Pedagogi. Vol. 3, No. 3.

Pembelajaran Matematika Pada Era Media Sosial dan Budaya POP. Jurnal Pendidikan Matematika. Vol. 1, No. 1.

Huda, Miftahul. (2013). Modelmodel Pengajaran dan Pembelajaran: Isu-isu Metodis dan Paragdimatis. Yogyakarta: Pustaka Pelajar.

Ismawati, N., N. Hindarto. (2011). Penerapan Model Pembelajaran Kooperatif Dengan Pendekatan Struktural Two Stay Two Stray Untuk Meningkatkan Hasil Belajar Siswa Kelas X SMA. Jurnal
Pendidikan Fisika Indonesia. Vol. 38, No. 41.

Mufidah, Lailatul., Dzulkifli Effendi., Titi Teri Purwanti. (2013). Penerapan Model Pembelajaran Kooperatif Tipe Tps Untuk Meningkatkan Aktivitas Belajar Siswa Pada Pokok Bahasan Matriks. Jurnal Pendidikan Matematika STKIP PGRI Sidoarjo. Vol.1, No.1.

Munir. (2012). Multimedia Konsep dan Aplikasi dalam Pendidikan. Bandung: Alfabeta.

Offirstson, Topic. (2014). Aktivitas Pembelajaran Matematika Melalui Inkuiri Berbantuan Software Cinderella. Yogyakarta: Deepublish.

Sudjana, Nana. (2005). Metoda dan Teknik Pembelajaran Partisipatif. Bandung: Falah Production.

Suprapti, Endang, et al. (2013). Pengembangan Perangkat Pembelajaran Model Pembelajaran Kooperatif Tipe Jigsaw Berbasis Komputer Pada Mata Kuliah Metode Numerik Melalui Program Lesson Study. Journal of Mathematics Education, Science and Technology. Vol. 13, No. 3.

$\begin{array}{lr}\text { Suprapti, Endang } & \begin{array}{r}(2016) . \\ \text { Pengembangan }\end{array} \\ \text { Perangkat } \\ \text { Pembelajaran } & \text { Matematika } \\ \text { Model Kooperatif Tipe STAD } \\ \text { dengan Media } & \text { Powerpoint } \\ \text { Ispring pada } & \text { Materi } \\ \text { Jajargenjang, Layang-layang, } \\ \text { dan Trapesium di Kelas VII } \\ \text { SMP. Journal of Mathematics }\end{array}$




\section{MATEMATICS PAEDAGOGIC}

Vol IV. No.1, September 2019, hlm. 1 - 11

Available online at www.jurnal.una.ac.id/indeks/jmp

Education, Science and Technology. Vol. 1, No. 1.

Afridati, Siti Maryam. (2018). Upaya Meningkatkan Aktivitas Peserta didik dan Hasil Belajar Matematika Barisan Bilangan dan Deret Melalui Penggunaan Pendekatan CTL Bagi Peserta didik Kelas IXA Semester Gasal SMP Ta'mirul Islam Surakarta Tahun Pelajaran 2017/2018. Jurnal Pendidikan Empirisme. Vol. 6, No. 4.

Shoffa, Shoffan dan Endang Suprapti. (2017). Peningkatan
Hasil Belajar Mahasiswa pada Mata Kuliah Metode Numerik dengan Model Pembelajaran kooperatif Jigsaw. Journal of Mathematics Education, Science and Technology. Vol. 2, No. 2.

Simamora, Lambok. (2014). Pengaruh Persepsi Peserta didik Tentang Kompetensi Pedagogik Guru Dan Kebiasaan Belajar Peserta didik Terhadap Prestasi Belajar Matematika. Jurnal Formatif. Vol. 4, No. 1. 